\title{
DIRECT AND AIRBORNE CONTACT DERMATITIS IN A BEEKEEPER FROM THE MAŁOPOLSKA REGION
}

\author{
KATARZYNA BASISTA \\ Jagiellonian University, Kraków, Poland \\ Department of Pharmacodynamics, Faculty of Pharmacy, Medical College
}

\begin{abstract}
The paper describes an atypical case of simultaneous airborne and direct contact dermatitis in a beekeeper from the Małopolska region. This is the third such case described in a beekeeper in the world and the first in Poland. I suggest that propolis should be regarded as both a direct and airborne contact allergen in beekeepers.
\end{abstract}

Key words:

Allergic contact dermatitis, Propolis, Beekeepers, Occupational diseases, Occupational allergy, Airborne contact dermatitis

\section{INTRODUCTION}

From 1986 to 2006 WHO received 29 reports of suspected side-effects of propolis (including contact and oral allergy). Although allergic contact dermatitis (ACD) to propolis seems to be rare in the healthy population [1], there have been described some cases of propolis allergy in beekeepers [2-7]. The first case of propolis allergic contact dermatitis was described in 1915 and referred to a beekeeper with contact dermatitis on his hands. Since that time, propolis has been recognized as an occupational contact allergen mainly in beekeepers [2].

\section{CASE REPORT}

A 62-year-old man, a beekeeper for over 35 years, was seen with an allergic contact dermatitis from propolis. It mainly manifested as periorbital eczema, but it also affected the hands when he did not use any protection.
This allergy occurred after over 20 years of beekeeping. It is worth mentioning that his father had also been a beekeeper, so he had been exposed to propolis since childhood. His brothers are also beekeepers, but nobody in his family is allergic to propolis. In order to confirm propolis allergy, skin tests with the European standard series and with $10 \%$ propolis were conducted. The tests showed only positive reactions to propolis and to perubalsam. The patient had not experienced any episode of allergy before. After the allergy occurred, cetirizinum and topical steroids were prescribed. He suffered from hypertension and because of that he was then taking metoprolol.

He continued beekeeping, but the symptoms worsened over time. Nowadays, he has symptoms such as facial itching, rash and lacrimation without any direct contact with propolis. This is a rare case of an atypical form of sensitization, airborne allergic contact dermatitis. The patient was advised to discontinue beekeeping by his physician and currently he is considering it very seriously.

Received: January 1, 2012. Accepted: July 9, 2012.

Address reprint request to K. Basista, Środkowa 11/2, 31-436 Kraków, Poland (e-mail: katarzyna.basista@gmail.com). 


\section{DISCUSSION}

This is the first report of simultaneous airborne contact dermatitis and direct contact dermatitis in a beekeeper from the Małopolska region. In world-wide literature, there have been described only three cases and only two of them were related to beekeepers $[6,8,9]$. The airborne contact dermatitis seems to be very rare and not many beekeepers or even physicians are conscious of this kind of allergy.

Münstedt et al. reported that the average time after which the allergy to propolis can start is 9.5 years [3]. In the discussed case, it was after over 20 years of beekeeping, not including the time of exposure to propolis during the subject's childhood. This case confirms that the development of contact dermatitis to propolis can occur after many years of beekeeping and, unfortunately, it can worsen over time. The main problem is that the only way to deal with this issue is to abandon beekeeping and avoid the antigens. This is a very detrimental alternative for beekeepers and very often they continue beekeeping despite the development of propolis allergy.

\section{CONCLUSION}

I conclude that the subject of contact allergy to propolis in the groups at risk, such as beekeepers, should be paid more attention. Beekeepers should protect themselves against the contact with propolis and they should consider not using propolis as a medicine. Furthermore, propolis should be regarded as both a direct and airborne contact allergen in this group.

\section{REFERENCES}

1. Walgrave SE, Warshaw EM, Glesne LA. Allergic contact dermatitis from propolis. Dermatitis 2005;16:209-15.

2. Münstedt K, Kalder M. Contact allergy to propolis in beekeepers. Allergol Immunopathol (Madr) 2009;37:298-301.

3. Münstedt K, Hellner M, Hackethal A, Winter D, von Georgi R. Contact allergy to propolis in beekeepers. Allergol Immunopathol (Madr) 2007;35:95-100.

4. Celikel S, Karakaya G, Yurtsever N, Sorkun K, Kalyoncu AF. Bee and bee products allergy in Turkish beekeepers: determination of risk factors for systemic reactions. Allergol Immunopathol (Madr) 2006;34:180-4.

5. Gulbahar O, Ozturk G, Erdem N, Kazandi AC, Kokuludag A. Psoriasiform contact dermatitis due to propolis in a beekeeper. Ann Allergy Asthma Immunol 2005;94:509-11.

6. Garrido Fernández S, Arroabarren Alemán E, García Figueroa BE, Goienetxe Fagoaga E, Olaguibel Rivera JM, Tabar Purroy AI. Direct and airborne contact dermatitis from propolis in beekeepers. Contact Dermatitis 2004;50:320-1.

7. Bousquet J, Menardo JL, Michel FB. Allergy in beekeepers. Allergol Immunopathol (Madr) 1982;10:395-8.

8. Kleinhans D. Airborne contact dermatitis due to propolis. Contact Dermatitis 1987;17:187-8.

9. Tobin AM, Kirby B. Airborne contact dermatitis induced by a neighbour's beehives. Contact Dermatitis 2003;49:214-5.

This work is available in Open Access model and licensed under a Creative Commons Attribution-NonCommercial 3.0 Poland License - http://creativecommons.org/ licenses/by-nc/3.0/pl/deed.en. 